\title{
PENGARUH MOTIVASI, SELF-EFFICACY DAN LATAR BELAKANG PENDIDIKAN TERHADAP PRESTASI MATEMATIKA MAHASISWA PGSD STKIP-H DAN PGMI IAIH
}

\author{
Syukrul Hamdi ${ }^{1)}$, Agus Maman Abadi ${ }^{2)}$ \\ STKIP Hamzanwadi Selong Lombok Timur NTB ${ }^{1)}$, Universitas Negeri Yogyakarta ${ }^{2)}$ \\ syukrulhamdi@gmail.com ${ }^{1)}$, agusmaman@uny.ac.id ${ }^{2)}$
}

\begin{abstract}
Abstrak
Tujuan dari penelitian ini adalah untuk mengetahui: (1) pengaruh motivasi, self-efficacy, dan latar belakang pendidikan terhadap prestasi matematika mahasiswa PGSD dan PGMI. (2) perbedaan pengaruh motivasi, self-efficacy, dan latar belakang pendidikan terhadap prestasi matematika mahasiswa PGSD dan PGMI. Jenis penelitian ini adalah penelitian survey dengan pendekatan kuantitatif. Hasil penelitian ini adalah sebagai berikut: (1) Rata-rata prestasi belajar matematika mahasiswa PGSD 57,95 (cukup) dan PGMI 50,93 (rendah); rata-rata motivasi mahasiswa PGSD 110 (tinggi) dan PGMI 99,57 (sedang); rata-rata self-efficacy mahasiswa PGSD 86,61 (tinggi) dan PGMI 81,55 (tinggi). (2) Motivasi, self-efficacy dan latar belakang pendidikan secara bersama-sama berpengaruh terhadap prestasi matematika mahasiswa PGSD dan PGMI. Berdasarkan hasil uji-t, motivasi dan self-efficacy masing-masing berpengaruh ter-hadap prestasi matematika mahasiswa PGSD dan PGMI sedangkan latar belakang pendidikan tidak berpengaruh terhadap prestasi matematika mereka. (3) Uji kesamaan menunjukkan ada perbedaan pengaruh motivasi dan self-efficacy terhadap prestasi matematika mahasiswa PGSD dan PGMI.
\end{abstract}

Kata kunci: motivasi, self-efficacy, latar belakang pendidikan, prestasi matematika

\section{THE EFFECT OF MOTIVATION, SELF-EFFICACY, AND EDUCATIONAL BACKGROUND ON THE MATHEMATICS ACHIEVEMENT OF THE STUDENTS OF PGSD STKIP-H AND PGMI IAIH}

\begin{abstract}
This study aims to determine: (1) the effect of motivation, self-efficacy, and educational background of the students of PGSD and PGMI in mathematics achievement; (2) the differences of the effect of motivation, self-efficacy, and educational background of the students of PGSD and PGMI on mathematics achievement. This research was a survey used the quantitative approach. The results of this study are as follows. (1) The average mathematics achievement of PGSD students is 57.95 (sufficient) and that of PGMI is 50.93 (low), the average motivation of PGSD students is 110 (high) and that of PGMI students is 99.57 (medium), the average self-efficacy of PGSD students is 86.61 (high) and that of PGMI students is 81.55 (high). (2) Moti-vation, self-efficacy and educational background of PGSD and PGMI students affect their mathematics achievement. The result of the t-test of motivation and self-efficacy affects the students' mathematics achievement, while educational background has no effect on the student mathematics achievement. (3) The result of the comparison test shows significant differences in the effect of motivation and self-efficacy in mathematics achievement of the students of PGSD and PGMI.
\end{abstract}

Keywords: motivation, self-efficacy, educational background, mathematics achievement 


\section{PENDAHULUAN}

Pendidikan dasar yang ditempuh oleh seseorang merupakan faktor penentu perkembangan kemampuan yang dimiliki, terutama pada jenjang sekolah dasar. Pendapat tersebut seseuai dengan teori yang diungkapkan oleh Collier, et.al (Suharningsih, 2010, p.104) yang menyatakan jika sekolah dasar sebagai salah satu bentuk pendidikan dasar merupakan satuan pendidikan yang paling penting keberadaannya. Teori tersebut diperkuat oleh Stoops \& Johnson (Suharningsih, 2010, p.104) yang menyatakan bahwa pendidikan di sekolah dasar merupakan dasar dari semua pendidikan. Teori-teori tersebut mengindikasikan jika keberhasilan seseorang mengikuti pendidikan di sekolah dasar menentukan keberhasilannya dalam mengikuti pendidikan selanjutnya. Dalam UU. No. 20 tahun 2003 tentang Sistem Pendidikan Nasional pasal 15 menandaskan bahwa: "jenis pendidikan mencakup pendidikan umum, kejuruan, akademik, profesi, keagamaan dan khusus". Jenis pendidikan keagamaan setingkat sekolah dasar dinamakan madrasah ibtitidaiyah.

Masing-masing lembaga pelaksana pendidikan yang berada di bawah kementrian pendidikan dan kementrian agama memiliki perbedaan dilihat dari segi beban mata pelajarannya. Hal itu ditemukan pada jenis mata pelajaran yang wajib diikuti serta pembiasaan teori dan praktik yang disesuaikan dengan masing-masing lembaga tersebut. Dengan kata lain, seseorang yang menempuh pendidikan pada salah satu sekolah yang berada di bawah lembaga keagamaan memiliki beban studi yang lebih banyak dibandingkan dengan sekolah yang berada di bawah lembaga pendidikan umum. Jumlah beban studi tersebut tentu saja terkait dengan mata pelajaran agama yang bersifat khusus yang wajib ditempuh oleh siswa di bawah lembaga keagamaan. Kondisi itu memberikan konsekuensi beban pada siswa yang menempuh pendidikan di sekolah keagamaan dibandingkan dengan siswa yang menempuh pendidikan di sekolah umum.

Matematika sebagai salah satu bagian dari disiplin ilmu yang dipelajari dalam setiap jenjang pendidikan memiliki konsep-konsep yang berhubungan satu dengan lainnya. Menurut Suherman, et al. (2001, p.59) "mempelajari matematika lebih lanjut harus mempelajari dulu matematika level sebelumnya. Seseorang yang ingin menjadi ilmuawan dalam bidang matematika, maka harus belajar dulu matematika mulai dari tingkat paling dasar", oleh karena itu dibutuhkan pembelajaran dan pengajaran dasar matematis yang kuat kepada semua siswa terutama pada jenjang pendidikan dasar setingkat SD atau MI serta SMP atau Madrasah Tsanawiah. Kondisi itu dibutuhkan agar siswa lebih mudah mempelajari matematika ketika berada pada jenjang SMA/MA dan perguruan tinggi. Prestasi matematika siswa SD/MI di Lombok Timur dapat dilihat dari hasil ujian nasional yang dirangkum dalam tabel 1 sebagai berikut:

Tabel 1. Nilai Rata-Rata UN Mata Pelajaran Matematika SD/MI Lombok Timur NTB

\begin{tabular}{ccc}
\hline Tahun Ajaran & SD & MI \\
\hline $2011 / 2012$ & 6,03 & 5,46 \\
$2010 / 2011$ & 5,69 & 4,65 \\
$2009 / 2010$ & 5,00 & 4,55 \\
\hline
\end{tabular}

(Sumber: Dikpora Lotim, 2012)

Berdasarkan data tersebut, terlihat bahwa prestasi matematika siswa SD dan MI belum bagus dan perlu ditingkatkan, antara lain dengan meningkatkan kualitas guru yang berawal dari pembinaan calon guru (mahasiswa calon guru SD ataupun MI) dengan baik dan professional. Selain itu, data statistik yang ada menunjukkan terdapat perbedaan hasil ujian nasional mata pelajaran matematika antara siswa yang sekolah di SD dengan MI. Data tersebut menunjukkan bahwa hasil ujian nasional siswa SD lebih tinggi dibandingkan dengan siswa MI. Fakta tersebut mengindikasikan permasalahan yang terjadi secara kontinyu terutama dari guru yang menjadi indikator utama dalam keberhasilan ujian nasional yang dilaksanakan. Hal ini harus menjadi perhatian serius pemerintah dan perguruan tinggi yang membina dan mendidik calon guru SD maupun MI sehingga memiliki dasar yang kuat dan memiliki kemampuan dalam mengajar terutama pelajaran matematika

Adapun faktor-faktor yang mempengaruhi prestasi belajar (Syah, 2010, p.129), diantaranya adalah faktor internal dan faktor eksternal. Berdasarkan pendapat ahli tersebut dapat diuraikan lebih spesifik masing-masing dari faktor yang mempengaruhi belajar, yang pertama faktor internal (faktor dari dalam mahasiswa), yakni keadaan atau kondisi jasmani dan rohani mahasiswa termasuk di dalamnya adalah motivasi dan self-efficacy yang dimiliki mahasiswa. Kedua adalah faktor eksternal (faktor dari luar diri mahasiswa), yakni kondisi lingkungan di sekitar siswa/mahasiswa, baik lingkungan keluarga, kampus maupun lingkungan masyarakat dan latar belakang pendidikan mahasiswa (sekolah). 
Hasil wawancara dengan dosen pengampu mata kuliah matematika yang mengajar di PGMI dan PGSD mengemukakan bahwa hasil yang diperlihatkan oleh mahasiswa PGMI tentang prestasi mata kuliah pendidikan matematika SD kurang efektif apabila dibandingkan dengan mahasiswa PGSD. Selain itu perbedaan yang mendasar juga terjadi pada nilai mata kuliah terkait matematika yang didapatkan oleh mahasiswa PGSD STKIP Hamzanwadi dan mahasiswa PGMI IAI Hamzanwadi dimana mahasiswa PGSD STKIP Hamzanwadi memiliki nilai lebih baik dibandingkan dengan mahasiswa PGMI IAI Hamzanwadi.

Prestasi matematika mahasiswa calon guru yang belum menggembirakan dilihat pula dari hasil ujian nasional yang diperoleh siswa SD/MI karena sebagian guru SD/MI adalah lulusan PGSD/PGMI. Dari uraian tersebut masalah dalam penelitian terbagi menjadi dua yakni: (1). Apakah terdapat pengaruh motivasi, selfefficacy, latar belakang pendidikan terhadap prestasi belajar matematika mahasiswa PGSD dan PGMI?, (2). Apakah terdapat perbedaan pengaruh motivasi, self-efficacy, dan latar belakang pendidikan terhadap prestasi belajar matematika mahasiswa PGSD dan PGMI? Penelitian ini bertujuan untuk: (1). Mengetahui pengaruh motivasi, self-efficacy, dan latar belakang pendidikan terhadap prestasi belajar matematika mahasiswa PGSD dan PGMI; (2). Mengetahui perbedaan pengaruh motivasi, self-efficacy, dan latar belakang pendidikan terhadap prestasi belajar matematika mahasiswa PGSD dan PGMI.

\section{Prestasi Belajar Matematika}

Menurut Van de Walle (2007, p.13) "Mathematics is the science of pattern and order". Yang berarti matematika adalah ilmu tentang pola dan urutan. Pendapat ini diperkuat oleh Skemp (1971, p.37) yang menyatakan bahwa konsep matematika yang satu dengan yang lain saling berkorelasi membentuk konsep baru yang lebih kompleks. Agar konsep-konsep matematika yang telah terbentuk itu dapat dipahami orang lain dan dapat dengan mudah dimanipulasi secara tepat, maka digunakan notasi dan istilah yang cermat yang disepakati secara global (universal) yang dikenal dengan bahasa matematika.

Dalam NCTM (2000, p.4) dijelaskan bahwa, kebutuhan untuk memahami dan menggunakan matematika dalam kehidupan seharihari akan semakin meningkat, sebagai contoh, (1). Mathematics for life: dasar-dasar kehidupan sehari-hari semakin banyak menerapkan konsep matematika dan teknologi. Misalnya, membuat keputusan pembelian, memilih asuransi atau rencana kesehatan, dan pemungutan suara pada pemilihan umum. (2). Mathematics as a part of cultural heritage: matematika adalah salah satu budaya dan prestasi intelektual terbesar umat manusia, serta setiap manusia harus mengembangkan apresiasi dan pemahamannya tentang matematika, termasuk estetika dan aspek rekreasi. (3).Mathematics for the workplace: pemikiran matematika dan pemecahan masalah sangat diperlukan di tempat kerja, di bidang profesional mulai dari perawatan kesehatan sampai desain grafis. (4). Mathematics for the scientific and technical community: semua pekerjaan membutuhkan dasar pengetahuan matematika, sehingga sangat wajar bila dikatakan bahwa matematika sebagai basic sains dan teknologi. Setiap mahasiswa harus memahami matematika untuk mempersiapkan diri mereka sebagai matematikawan, ahli statistik, insinyur, dan scientists.

Menurut Schunk (2012, p.3), "Learning is an enduring change in behavior, or in the capacity to behave in a given fashion, which results from practice or other forms of experience". Yang maknanya belajar merupakan perubahan perilaku yang bertahan lama, atau dalam kapasitas berperilaku dengan cara tertentu, yang dihasilkan dari praktik atau bentuk-bentuk pengalaman lainnya.

Arends \& Kilcher (2010, p.59) berpendapat bahwa "achievement is satisfied when students strive to learn particular subjects or acquire difficult skills and are successful in their quest". Maksudnya bahwa prestasi merupakan hasil ketika mahasiswa berusaha untuk mempelajari mata pelajaran tertentu atau memperoleh keterampilan yang sulit dan berhasil dalam upaya mereka.

Prestasi belajar oleh Schwan (2002, p.1) didefinisikan sebagai sebuah pencapaian peserta didik dalam proses pembelajaran yang meliputi berbagai kemampuan akademik seperti membaca, menulis, dan kemampuan matematis dalam bentuk skor yang ditentukan oleh guru.

Menurut Brown \& McNamara (2005, p.16) prestasi belajar matematika, yaitu: "Mathematical achievement is understood more in term of performance of prescribed mathematical procedures. This is quantifiable through diagnostic testing, and broader understanding is anchored around test indicators in a statistically defined environment" Makna dari penyataan 
tersebut yaitu prestasi matematika dipahami lebih dalam dari hal kinerja prosedur matematika yang ditentukan. Hal ini diukur melalui tes diagnostik, dan pemahaman lebih luas bermula dari indikator tes didefinisikan dalam lingkungan statistik. Berdasarkan pendapat Brown \& McNamara tersebut maka pengukuran prestasi belajar matematika dapat diketahui lewat tes yang dibuat berdasarkan indikator-indikator yang sesuai dengan kemampuan yang akan diukur.

\section{Motivasi}

Ada beberapa pengertian yang dipergunakan untuk menjabarkan istilah motivasi. Terkait dengan hal tersebut, Wade \& Tavris (2011, p.431) mendefinisikan motivasi berdasarkan etimologinya, yakni "The word motivation, like the word emotion, comes from the Latin root meaning 'to move"' motivasi diartikan berdasarkan asal katanya seperti halnya kata emosi, berasal dari bahasa latin yang berarti bergerak. Makna harfiah dari kata bergerak bisa kita simpulkan sebagai sesuatu yang terus mengalami perubahan, sesuai dengan situasi dan kondisi individu yang menjalaninya serta perkembangan zaman yang mengikutinya. Pendapat ini diperkuat pendapat Hannula (Waege, 2009, p.85) "motivasi adalah potensi untuk mengarahkan tingkah laku yang dibangun ke dalam sistem yang mengontrol emosi. Potensi ini dapat diwujudkan dalam kognisi, emosi dan/atau perilaku".

Pendapat tentang difinisi motivasi juga dinyatakan oleh Schunk (2012, p.58) dengan mendefinisikannya sebagai proses dimana aktivitas-aktivitas yang berorientasi target dibuat terjadi dan dipertahankan kelangsungannya. Definisi tersebut diperkuat oleh pendapat Santrock (2011, p.510) yang menyatakan motivasi sebagai proses yang memberi semangat, arah, dan kegigihan perilaku. Artinya, perilaku yang termotivasi adalah perilaku yang penuh energi, terarah dan bertahan lama.

Pendapat para ahli di atas mengindikasikan beberapa kata kunci yang diawali oleh makna harfiah (asal kata) dari motivasi itu sendiri yang diartikan sebagai gerakan, yang diikuti oleh target, semangat dan kegigihan. Dari beberapa kata kunci yang dijabarkan oleh para ahli tersebut kita bisa menyimpulkan jika motivasi adalah sebuah desakan yang berbentuk gerakan karena adanya target, semangat yang tinggi dan usaha yang gigih untuk mencapainya. Dengan kata lain, motivasi mengindikasikan adanya gerakan atau perubahan tingkah laku yang dilakukan oleh seseorang karena ingin mencapai target atau tujuan tertentu sehingga menimbulkan semangat yang tinggi serta usaha yang gigih agar terget tersebut dapat dicapai dengan maksimal.

\section{Self-efficacy}

Self-efficacy memiliki dampak yang positif pada berbagai aspek kehidupan seseorang terutama dalam pembelajaran sebagaimana diungkapkan Zimmerman, Sebastian, \& Robert (1996, p.27) self-efficacy merupakan variabel penting bagi siswa untuk evaluasi karena memfokuskan perhatian pada keyakinan mereka tentang efektifitas metode pembelajaran mereka. Bandura (Friedman \& Schustack, 2008, p.283) menyebutkan definisi "self-efficacy adalah ekspektasikeyakinan (harapan) tentang seberapa jauh seseorang mampu melakukan satu prilaku dalam suatu situasi tertentu". Pendapat lain "selfefficacy adalah keyakinan seseorang bahwa dirinya mampu meraih hasil yang diinginkan, seperti penguasaan suatu keterampilan baru atau mencapai suatu tujuan" (Wade \& Tavris, 2007, p.180). Pendapat-pendapat para ahli terkait selfefficacy tersebut menunjukkan bahwa selfefficacy memiliki peranan yang cukup penting untuk mencapai tujuan seseorang.

Pendapat yang sama juga diungkapkan oleh Santrock (2011b, p.473) yang menyebutkan "Self-efficacy is the belief that one can master a situation and produce positive outcomes". Woolfolk (2007, p.392) "Self-efficacy is our belief about our personal competence or effectiveness in a given area and important variable for students to monitor. Secara umum, definisi di atas menjelaskan self-efficacy sebagai keyakinan yang bisa mendorong atau mengarahkan seseorang untuk menemukan solusi dalam sebuah situasi dan mampu menghasilkan sikap positif dari situasi yang terjadi tersebut. Dengan kata lain self-efficacy menjadi kunci dan stimulus utama yang bisa membantu seseorang menemukan solusi atau jalan keluar dari sebuah situasi yang sedang dihadapi. Sedangkan pendapat Wolfolk di atas lebih mendefinisikan selfefficacy sebagai keyakinan diri terhadap kompetensi atau kesanggupan pribadi yang dimiliki pada berbagai keadaan yang diberikan atau ditemukan.

Definisi-definisi tentang Self-efficacy atau keyakinan diri tersebut menjabarkan fungsi keyakinan diri yang menjadi sebuah variabel penting bagi siswa/mahasiswa untuk mengontrol 
berbagai situasi dan kondisi yang ditemukan berdasarkan kesadaran diri akan keberadaannya supaya bisa menguatkan keyakinan diri mereka. Keadaan itu nantinya akan menjadi dasar untuk menemukan sebuah metode pembelajaran yang lebih epektif sehingga dapat menghasilkan output yang lebih baik pula. Secara sederhana, definisi tersebut memiliki keterkaitan dengan evaluasi pribadi yang bisa dilakukan oleh seseorang sehingga terjadi perubahan positif yang lebih mendorong mereka untuk bersikap optimis terhadap berbagai situasi dan tempat berbeda.

Tanpa adanya keyakinan diri maka seseorang akan terus terhimpit dalam setiap permasalahan yang ia hadapi karena tidak mampu menemukan solusi yang tepat. Hal itu disebabkan karena mereka merasa sudah tidak berdaya sejak awal. Di samping itu, ketiadaan selfefficacy atau keyakinan diri pada seseoarang akan mengakibatkan mereka sulit untuk menghasilkan suatu perubahan yang lebih baik karena mereka sendiri tidak memahami kemampuan yang mereka miliki serta tidak berdaya mengendalikan setiap situasi yang ditemukan dalam kehidupan.

Dari beberapa pendapat ahli tersebut dapat disimpulkan bahwa self-efficacy adalah keyakinan diri yang bisa mengarahkan seseorang untuk menemukan solusi dalam sebuah situasi dan mampu menghasilkan sikap positif dari situasi yang terjadi.

Adapun cara mengatur self-efficacy dalam pencapaian prestasi diungkapkan Bandura (1997, p.214) bahwa ada tiga cara utama di mana keyakinan diri mengoperasikan kontributor penting untuk mengembangkan kompetensi kognitif yang mengatur prestasi akademik: keyakinan siswa dalam keberhasilan mereka untuk menguasai mata pelajaran akademik yang berbeda, keyakinan guru dalam keberhasilan pribadi mereka untuk mendukung dan mempromosikan pembelajaran pada siswa mereka, dan penggabungan ide atau pemikiran lembaga jika para siswa dan guru dapat berhasil mencapai kemajuan akademis yang signifikan.

\section{Latar Belakang Pendidikan}

Latar belakang pendidikan yang dimaksud adalah pendidikan yang ditempuh oleh mahasiswa sebelum perguruan tinggi khususnya untuk mendapatkan gelar sarjana atau strata satu di antaranya yakni pendidikan SMA/SMK dan MA. Pada umumnya, jenjang pendidikan yang telah ditempuh sebelumnya memiliki hubungan dan pengaruh yang kuat terhadap kemampuan pemecahan masalah dalam proses pembelajaran, baik ketika mereka berada pada lingkungan tempat menjalankan tugas sebagai mahasiswa maupun sebagai seorang pendidik. Menurut Schunk (2012, p.441) "Variabel yang mempengaruhi prestasi matematika ialah transisi antara sekolah". "Transisi antara sekolah, misalnya, anak pra-sekolah masuk ke SD, siswa SD masuk ke SMP, siswa SMP masuk ke SMA dan siswa SMA masuk ke Universitas" (Schunk, 2012, p.463).

Transisi dari sekolah menengah atas menuju universitas melibatkan gerakan menuju satu struktur sekolah yang lebih besar dan tidak bersifat pribadi; interaksi dari dengan kelompok sebaya dari daerah yang lebih beragam dan kadang lebih beragam latar belakang etnisnya; dan peningkatan perhartian pada prestasi dan penilaiannya (Santrock, 2008, p.461).

Pendapat lain dikemukakan oleh Kahn \& Kyle (Ed.) (2005, p.15) yang menyebutkan transisi ke situasi lain dan fase pendidikan atau pekerjaan selalu akan menyebabkan beberapa masalah bagi mahasiswa atau siapapun. Harus ada inisiatif atau tujuan baik untuk mengurangi kemungkinan masalah ini dengan mendiagnosa mereka yang mampu bertahan dan menawarkan dukungan bagi mereka yang terkena dampak atau kesulitan dalam menghadapi masalah. Menurut Berk (2008, p.579) "kesulitan pemuda dalam masa sekolah menjadi rendah atau menurun drastis setelah masa transisi sekolah. Hal tesebut ditunjukkan dengan pola rendahnya kepercayaan diri, motivasi dan prestasi”.

\section{METODE PENELITIAN}

Penelitian ini menggunakan pendekatan kuantitatif. Jenis penelitian yang digunakan adalah penelitian survey. Desain penelitian yang akan digunakan peneliti seperti gambar 1 berikut ini.

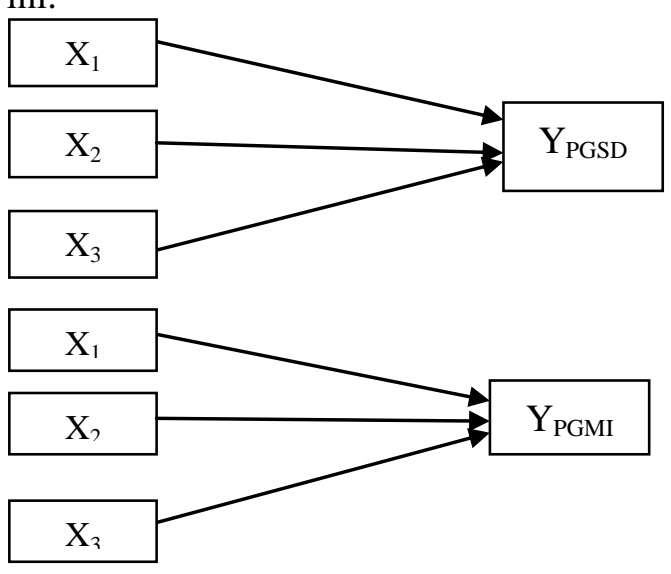

Gambar 1. Desain Penelitian 


\section{Instrumen Pengumpulan Data}

Tes Prestasi Belajar Matematika

Angket Motivasi, dan

Angket self-efficacy

\section{Teknik Analisis Data}

Analisis Deskripsi

Data yang berupa skor motivasi dan selfefficacy yang diperoleh dalam bentuk kategori yang terdiri dari lima pilihan yaitu sangat tinggi (5), tinggi (4), sedang (3), rendah (2), sangat rendah (1) dirubah menjadi data interval.

Skor yang diperoleh kemudian dikonversikan menjadi data kualitatif skala lima, dengan acuan rumus yang dikutip dari acuan rumus yang diadaptasi dari Azwar (2012, p.163) yang disajikan pada tabel berikut.

Tabel 2. Konversi Skor Aktual Menjadi Nilai Skala Lima

\begin{tabular}{cc}
\hline Interval skor & Kriteria \\
\hline $\mathrm{Mi}+1,5 \mathrm{SDi}<\mathrm{X} \leq \mathrm{Mi}+3 \mathrm{SDi}$ & Sangat tinggi \\
$\mathrm{Mi}+0,5 \mathrm{SDi}<\mathrm{X} \leq \mathrm{Mi}+1,5 \mathrm{SDi}$ & Tinggi \\
$\mathrm{Mi}-0,5 \mathrm{SDi}<\mathrm{X} \leq \mathrm{Mi}+0,5 \mathrm{SDi}$ & Sedang \\
$\mathrm{Mi}-1,5 \mathrm{SDi}<\mathrm{X} \leq \mathrm{Mi}-0,5 \mathrm{SDi}$ & Rendah \\
$\mathrm{Mi}-3 \mathrm{SDi} \leq \mathrm{X} \leq \mathrm{Mi}-1,5 \mathrm{SDi}$ & Sangat Rendah \\
\hline
\end{tabular}

Keterangan:

$\mathrm{Mi}=$ rerata skor ideal $=\frac{1}{2}$ (skor maksimum ideal + skor minimum ideal)

$\mathrm{SDi}=$ Standar Deviasi ideal $=\frac{1}{6}$ (skor maksimum ideal - skor minimum ideal)

$\mathrm{X}=$ Total skor aktual

Analisis Regresi Ganda

Asumsi yang harus dipenuhi dalam analisis regresi ganda yaitu multikolinieritas, heteroskedastisitas, normalitas, dan autokorelasi

Teknik analisa regresi linier ganda dengan tiga variabel bebas menggunakan taraf signifikansi 0,05 dengan persamaan sebagai berikut.

$$
Y=\beta_{\mathrm{o}}+\beta_{1} X_{1}+\beta_{2} X_{2}+\beta_{3} X_{3}+\varepsilon
$$

Keterangan :

$\mathrm{Y}=$ Prestasi Matematika Mahasiswa

$\beta_{0}=$ konstanta regresi

$\beta_{1}=$ koefisien motivasi

$\beta_{2}=$ koefisien self-efficacy

$\beta_{3}=$ koefisien latar belakang pendidikan

$\mathrm{X}_{1}, \mathrm{X}_{2}, \mathrm{X}_{3}=$ variabel bebas (motivasi, selfefficacy dan latar belakang pendidikan)

$\varepsilon=$ faktor error
Model regresi linier dapat digunakan atau tidak, maka diuji menggunakan uji anava dengan rumus sebagai berikut:

$F=\frac{R^{2} / k}{\left(1-R^{2}\right) /(n-k-1)}$ dengan $k$ dan $(n-k-1) d f$

(Steven, 2009, p.72)

dimana

$$
R^{2}=\frac{\sum\left(\hat{y}_{i}-\bar{y}\right)^{2}}{\sum\left(y_{i}-\bar{y}\right)^{2}}=\frac{S S_{r e g}}{S S_{t o t}}
$$

Untuk mengetahui apakah ada pengaruh masing-masing variabel bebas terhadap variabel terikat digunakan uji parsial dengan uji-t sebagai berikut:

$$
\mathrm{t}=\frac{b_{j}}{s . e\left(b_{j}\right)}
$$

Uji Kesamaan Menggunakan Two-Sample T Test (Dummy Variables in Regression)

Masing-masing variabel dalam hal ini motivasi dan self-efficacy akan diuji secara terpisah dan dibentuk regresi untuk PGSD dan PGMI sebagai berikut:

Misalkan

$\mathrm{Ys}_{\mathrm{S}}=\mathrm{Y}_{\mathrm{PGSD}}$

$\mathrm{Y}_{\mathrm{M}}=\mathrm{Y}_{\mathrm{PGMI}}$

$$
Y_{S}=\hat{\beta}_{0 s}+\widehat{\beta}_{1 s} X
$$

dan

$$
Y_{M}=\hat{\beta}_{0 M}+\widehat{\beta}_{1 M} X
$$

Yang pertama uji kesamaan untuk membandingkan slope dua regresi menggunakan rumus sebagai berikut:

$T=\frac{\hat{\beta}_{1 S}-\hat{\beta}_{1 M}}{S_{\left(\hat{\beta}_{1 S}-\hat{\beta}_{1 M}\right)}}$

(Kleinbaum, et.al.,2008, p.223)

dimana

$\hat{\beta}_{1 S}=$ kuadrat terkecil penghitungan slope $\beta_{1 S}$ menggunakan observasi $\mathrm{n}_{\mathbf{S}}$ (pada PGSD) $\hat{\beta}_{1 M}=$ kuadrat terkecil penghitungan slope $\beta_{1 M}$ menggunakan observasi $\mathrm{n}_{\mathrm{M}}$ (pada PGMI) $S_{\left(\hat{\beta}_{1 S}-\hat{\beta}_{1 M}\right)}=$ hasil penghitungan standard error of the estimated perbedaan antar slopes $\left(\hat{\beta}_{1 S}-\hat{\beta}_{1 M}\right)$ 
Untuk menghitung $S_{\left(\widehat{\beta}_{1 S}-\widehat{\beta}_{1 M}\right)}$ menggunakan rumus:

$s_{\left(\hat{\beta}_{2 S}-\hat{\beta}_{2 N}\right)}^{2}=s_{P . Y \mid X}^{2}\left[\frac{1}{\left(n_{S}-1\right) s_{X_{S}}^{2}}+\frac{1}{\left(n_{M}-1\right) s_{X_{M}}^{2}}\right]$

dimana

$S_{P, Y \mid X}^{2}=\frac{\left(n_{S}-2\right) s_{Y \mid X_{S}}+\left(n_{M}-2\right) s_{Y}^{n} \mid X_{M}}{n_{S}+n_{M}-4}$

Keterangan

$S_{Y \mid X_{S}}^{2}=$ residual mean-square error untuk data PGSD

$S_{Y \mid X_{M}}^{2}=$ residual mean-square error untuk data PGMI

$S_{X S}^{2}=$ Varian X untuk data PGSD

$S_{X_{M}}^{2}=$ Varian $X$ untuk data PGMI

Hipotesis yang diuji:

$H_{0}: \beta_{1 S}=\beta_{1 M}$

$H_{A}: \beta_{1 S} \neq \beta_{1 M}$

Kriteria keputusan yaitu tolak $\mathrm{H}_{0} \mathrm{jika}$

$|T|>t_{n_{S}+n_{M}-4_{i, 1}-\alpha / 2}$

Kedua adalah uji kesamaan untuk membandingkan dua intercepts menggunakan rumus sebagai berikut:

$T=\frac{\hat{\beta}_{O S}-\hat{\beta}_{0 M}}{S_{\left(\hat{\beta}_{O S}-\hat{\beta}_{O M}\right)}}$

Untuk menghitung $S_{\left(\hat{\beta}_{0 S}-\widehat{\beta}_{0 M}\right)}^{2}$ menggunakan rumus:

$S_{\left(\beta_{0 S}-\beta_{0 M}\right)}^{2}=S_{P, Y I X}^{2}\left[\frac{1}{n_{S}}+\frac{1}{n_{M}}+\frac{\bar{X}_{S}^{2}}{\left(n_{S}-1\right) S_{X_{S}}^{2}}+\frac{\bar{X}_{M}^{2}}{\left(n_{M}-1\right) S_{X_{M}}^{2}}\right]$

Hipotesis yang di uji:

$H_{0}: \beta_{0 S}=\beta_{0 M}$

$H_{A}: \beta_{0 S} \neq \beta_{0 M}$

Kriteria keputusan yaitu tolak $\mathrm{H}_{0}$ jika $|T| \geq t_{n_{S}+n_{M}-4_{;} 1-\alpha / 2}$

\section{HASIL PENELITIAN}

\section{Analisis Deskriftif}

Prestasi Belajar Matematika Mahasiswa PGSD dan PGMI

Berdasarkan analisis statistik, data variabel prestasi belajar matematika mahasiswa PGSD yang menjadi sampel penelitian memiliki rentang skor 16 sampai 88. Prestasi belajar matematika mahasiswa diperoleh dari tes matematika yang diberikan. Hasil analisis dengan bantuan SPSS 16.0 menunjukkan bahwa variabel prestasi belajar matematika mahasiswa PGSD yang berlatar belakang pendidikan SMA/ SMK memiliki rerata sebesar 59,54 masuk dalam kategori cukup sedangkan yang berlatar belakang pendidikan MA memiliki rerata sebesar 56,27 masuk dalam kategori cukup. Perolehan skor variabel prestasi belajar matematika mahasiswa PGSD secara umum memiliki rerata sebesar 57,95 masuk dalam kategori cukup dan simpangan baku 11,916.

Sedangkan untuk variabel prestasi belajar Matematika mahasiswa PGMI yang menjadi sampel penelitian memiliki rentang skor 8 sampai 76. Prestasi belajar Matematika mahasiswa diperoleh dari tes matematika yang diberikan. Hasil analisis dengan bantuan SPSS 16.0 menunjukkan bahwa variabel prestasi belajar matematika mahasiswa PGMI yang berlatar belakang pendidikan SMA/SMK memiliki rerata sebesar 52,50 masuk dalam kategori kurang sedangkan yang berlatar belakang pendidikan MA memiliki rerata sebesar 50,30 masuk dalam kategori kurang. Secara umum variabel prestasi belajar matematika mahasiswa PGMI memiliki rerata sebesar 50,93 masuk dalam kategori kurang dan simpangan baku 14,013.

\section{Motivasi Mahasiswa PGSD dan PGMI}

Berdasarkan analisis statistik, data variabel motivasi mahasiswa PGSD memiliki rentang skor 67 sampai 142. Skor motivasi diperoleh dari skor angket mahasiswa. Hasil analisis dengan bantuan SPSS 16.0 menunjukkan bahwa variabel motivasi belajar mahasiswa PGSD yang berlatar belakang pendidikan SMA/SMK memiliki rerata sebesar 112,58 masuk dalam kategori tinggi dan yang berlatar belakang pendidikan MA memiliki rerata sebesar 107,28 masuk dalam kategori tinggi. Variabel motivasi belajar mahasiswa secara umum memiliki rerata sebesar 110 masuk dalam kategori tinggi dan simpangan baku 14,207.

Sedangkan variabel motivasi mahasiswa PGMI memiliki rentang skor 66 sampai 132. Skor motivasi diperoleh dari skor angket mahasiswa. Hasil analisis dengan bantuan SPSS 16.0 menunjukkan bahwa variabel motivasi belajar mahasiswa PGMI yang berlatar belakang pendidikan SMA/SMK memiliki rerata sebesar 103,44 masuk dalam kategori sedang dan yang berlatar belakang pendidikan MA memiliki rerata sebesar 98,02 masuk dalam kategori sedang. Variabel motivasi belajar mahasiswa PGMI secara umum memiliki rerata sebesar 99,57 masuk 
dalam kategori sedang dan simpangan baku 14,70 .

\section{Self-efficacy Mahasiswa PGSD dan PGMI}

Berdasarkan analisis statistik, data variabel self-efficacy mahasiswa PGSD memiliki rentang skor 66 sampai 111. Skor self-efficacy tersebut diperoleh dari angket mahasiswa. Hasil analisis dengan bantuan SPSS 16.0 menunjukkan bahwa variabel self-efficacy belajar mahasiswa PGSD yang berlatar belakang pendidikan SMA/SMK memiliki rerata sebesar 88,10 masuk dalam kategori tinggi dan yang berlatar belakang pendidikan MA memiliki rerata sebesar 85,03 masuk dalam kategori tinggi. Variabel self-efficacy mahasiswa PGSD secara umum memiliki rerata sebesar 86,61 dan simpangan baku 11,099.

Sedangkan variabel self-efficacy mahasiswa PGMI memiliki rentang skor 53 sampai 102. Skor self-efficacy tersebut diperoleh dari angket mahasiswa. Hasil analisis dengan bantuan SPSS 16.0 menunjukkan bahwa variabel selfefficacy belajar mahasiswa PGMI yang berlatar belakang pendidikan SMA/SMK memiliki rerata sebesar 85,44 masuk dalam kategori tinggi dan yang berlatar belakang pendidikan MA memiliki rerata sebesar 80,00 masuk dalam kategori sedang. Variabel self-efficacy mahasiswa PGMI secara umum memiliki rerata sebesar 81,55 masuk dalam kategori tinggi dan simpangan baku 11,12 .

\section{Latar Belakang Pendidikan Mahasiswa PGSD} dan PGMI

Latar belakang pendidikan mahasiswa peneliti bagi menjadi 2 yakni yang menempuh di Madrasah Aliyah dan Sekolah Menengah Atas/ Sekolah Menengah Kejuruan. Berdasarkan data yang di dapat dari 152 sampel mahasiswa PGSD terdapat 74 mahasiswa yang menempuh pendidikan di Madrasah Aliyah (MA) atau 48,7\% dan 78 mahasiswa yang menempuh pendidikan di Sekolah Menengah Atas/Sekolah Menengah Kejuruan (SMA/SMK) atau 51,3\%.

Sedangkan latar belakang pendidikan mahasiswa PGMI dari 56 sampel mahasiswa PGMI terdapat 40 mahasiswa yang menempuh pendidikan di Madrasah Aliyah (MA) atau 71,4\% dan 16 mahasiswa yang menempuh pendidikan di Sekolah Menengah Atas/Sekolah Menengah Kejuruan (SMA/SMK) atau 28,6\%.

\section{Analisis Regresi PGSD dan PGMI}

Berdasarkan hasil analisis koefisien determinasi PGSD didapat besarnya adjusted $\mathrm{R}^{2}$ adalah 0,278 , hal ini berarti $27,8 \%$ variasi prestasi matematika mahasiswa dapat dijelaskan oleh variasi dari ke tiga variabel independen motivasi mahasiswa, self-efficacy mahasiswa dan latar belakang pendidikan mahasiswa. Sedangkan sisanya $(100 \%-27,8 \%=72,2 \%)$ dijelaskan oleh sebab-sebab yang lain di luar variabel independen.

Sedangkan koefisien determinasi PGMI didapat besarnya adjusted $\mathrm{R}^{2}$ adalah 0,568 , hal ini berarti $56,8 \%$ variasi prestasi matematika mahasiswa dapat dijelaskan oleh variasi dari ke tiga variabel independen motivasi mahasiswa, self-efficacy mahasiswa dan latar belakang pendidikan mahasiswa. Sedangkan sisanya (100\%$56,8 \%=43,2 \%)$ dijelaskan oleh sebab-sebab yang lain di luar variabel independent.

Dari hasil uji ANOVA atau F test di dapat nilai $\mathrm{F}$ hitung sebesar 20,351 dengan probabilitas 0,000 . Karena probabilitas jauh lebih kecil dari 0,05 , maka $\mathrm{H}_{0}$ ditolak atau dapat dikatakan bahwa motivasi, self-efficacy dan latar belakang pendidikan mahasiswa secara bersama-sama berpengaruh terhadap prestasi matematika mahasiswa. Sedangkan untuk mahasiswa PGMI hasil uji ANOVA atau $F$ test di dapat nilai $F$ hitung sebesar 25,144 dengan probabilitas 0,000 . Karena probabilitas jauh lebih kecil dari 0,05 , maka $\mathrm{H}_{0}$ ditolak atau dapat dikatakan bahwa motivasi, self-efficacy dan latar belakang pendidikan mahasiswa secara bersama-sama berpengaruh terhadap prestasi matematika mahasiswa.

Hasil uji signifikan parameter individual motivasi PGSD didapatkan nilai signifikansi sebesar 0,038 maka $\mathrm{H}_{\mathrm{o}}$ ditolak atau dapat dikatakan motivasi berpengaruh terhadap prestasi belajar matematika mahasiswa PGSD. begitu juga hasil uji signifikan parameter individual motivasi PGMI terlihat bahwa nilai signifikansi sebesar 0,000 maka $\mathrm{H}_{\mathrm{o}}$ ditolak atau dapat dikatakan motivasi berpengaruh terhadap prestasi belajar matemtika mahasiswa PGMI.

Hasil uji signifikan parameter individual self-efficacy PGSD didapatkan nilai signifikansi sebesar 0,000 maka $\mathrm{H}_{\mathrm{o}}$ ditolak atau dapat dikatakan self-efficacy berpengaruh terhadap prestasi belajar matemtika mahasiswa PGSD. Begitu juga hasil uji signifikan parameter individual selfefficacy PGMI terlihat bahwa nilai signifikansi sebesar 0,021 maka $\mathrm{H}_{\mathrm{o}}$ ditolak atau dapat dikata- 
kan self-efficacy berpengaruh terhadap prestasi belajar matematika mahasiswa PGMI

Hasil uji signifikan parameter individual latar belakang pendidikan mahasiswa PGSD didapatkan nilai signifikansi sebesar 0,493 maka $\mathrm{H}_{\mathrm{o}}$ diterima atau dapat dikatakan latar belakang pendidikan mahasiswa tidak berpengaruh terhadap prestasi belajar matematika mahasiswa PGSD. begitu juga hasil uji signifikan parameter individual latar belakang pendidikan mahasiswa PGMI didapatkan nilai signifikansi sebesar 0,335 maka $\mathrm{H}_{\mathrm{o}}$ diterima atau dapat dikatakan latar belakang pendidikan mahasiswa tidak berpengaruh terhadap prestasi belajar matemtika mahasiswa PGMI.

Tidak berpengaruhnya latar belakang pendidikan mahasiswa terhadap prestasi belajar matematika di PGSD dan PGMI karena latar belakang pendidikan mahasiswa berasal dari sekolah menengah yang relatif sama dari segi kualitas dan jika digolongkan antar negeri dan swasta juga merata, karena sebagian sekolah swasta mampu bersaing dengan sekolah negeri malah lebih dari sekolah negeri karena memiliki nilai plus seperti MA NW Pancor dan MA Muallimat NW Pancor yang mendominasi mahasiswa PGSD memiliki kualitas yang tidak kalah dengan negeri serta memiliki akreditasi A. Dari data yang peneliti dapatkan mahasiswa PGSD $42,11 \%$ di sekolah menengah swasta $37,5 \%$ MA dan 4,61\% SMA/SMK) dan 57,89\% di sekolah menengah negeri $(11,18 \%$ MAN dan $46,71 \%$ SMAN/SMKN). Begitu juga dengan mahasiswa yang berlatar belakang pendidikan MAN mampu bersaing dengan SMAN karena $11,18 \%$ mahasiswa yang berasal dari MAN itu adalah MAN terbaik di Lombok Timur yaitu MAN Selong.

Begitu juga halnya dengan mahasiswa PGMI, dari data yang didapatkan $75 \%$ mahasiswa PGMI di sekolah menengah swasta (64,29\% MA dan 10,71\% SMA/SMK) dan 25\% di sekolah menengah negeri $(7,14 \%$ MAN dan 17,86\% SMAN/SMKN) hal ini menggambarkan mahasiswa PGMI dominan berlatar belakang pendidikan swasta. Walaupun berlatar belakang sekolah/madrasah swasta kualitasnya tidak jauh berbeda dengan sekolah/madrasah negeri hal ini dilihat dari SMAN/SMKN latar belakang mahasiswa PGMI tidak ada dalam kategori sekolah unggulan di Lombok Timur dan beberapa mahasiswa PGMI berasal dari MAN kategori unggulan.

Dari hasil perolehan skor prestasi belajar matematika mahasiswa juga memperlihatkan ti- dak terdapat perbedaan hasil yang signifikan antara mahasiswa berlatar belakang pendidikan SMA/SMK dan MA baik di PGSD maupun PGMI. Perolehan skor dalam tabel 18 tersebut menunjukkan bahwa variabel prestasi belajar matematika mahasiswa PGSD yang berlatar belakang pendidikan SMA/SMK memiliki rerata sebesar 59,54 masuk dalam kategori cukup sedangkan yang berlatar belakang pendidikan MA memiliki rerata sebesar 56,27 masuk dalam kategori cukup. Dan variabel prestasi belajar matematika mahasiswa PGMI yang berlatar belakang pendidikan SMA/SMK memiliki rerata sebesar 52,50 masuk dalam kategori kurang sedangkan yang berlatar belakang pendidikan MA memiliki rerata sebesar 50,30 masuk dalam kategori kurang

Hasil uji kesamaan variabel motivasi didapatkan nilai $\mathrm{t}$ untuk membandingkan slope sebesar $-3,952$. Karena $|T|=3,952>1,960$ maka tolak $\mathrm{H}_{0}$ atau dapat dikatakan terdapat perbedaan slope. Dan nilai t untuk membandingkan dua intercept sebesar 3,718. Karena $|T|=3,718 \geq 1,960$ maka tolak $\mathrm{H}_{0}$ atau dapat dikatakan terdapat perbedaan dua intercept. Grafik dari hasil uji kesamaan tersebut sebagai berikut:

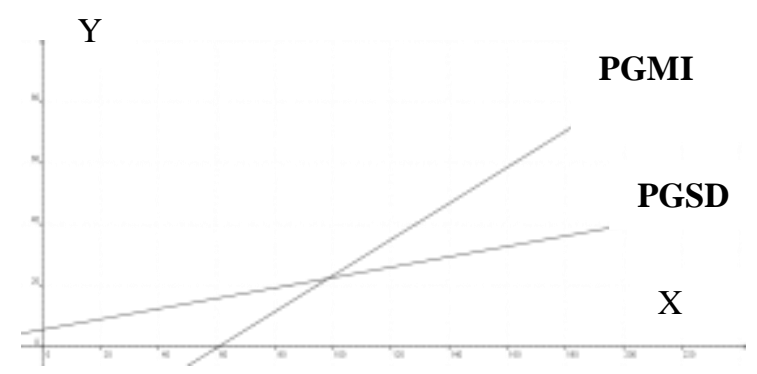

Gambar 2. Grafik Uji Kesamaan Variabel Motivasi

Hasil uji kesamaan variabel self-efficacy didapatkan bahwa nilai t untuk membandingkan slope sebesar 0,557 Karena $|T|=0,557<1,960$ maka terima $\mathrm{H}_{0}$ atau dapat dikatakan tidak terdapat perbedaan slope. Dan nilai $\mathrm{t}$ untuk membandingkan dua intercept sebesar 3,525. Karena $|T|=3,525 \geq 1,960$ maka tolak $\mathrm{H}_{0}$ atau dapat dikatakan terdapat perbedaan dua intercept. Grafik dari hasil uji kesamaan tersebut sebagai berikut: 


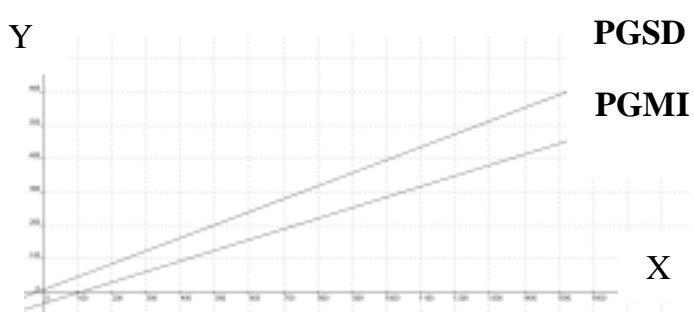

Gambar 3. Grafik Uji Kesamaan Variabel Selfefficacy

\section{SIMPULAN DAN SARAN}

\section{Simpulan}

Berdasarkan uji anava didapatkan motivasi, self-efficacy dan latar belakang pendidikan mahasiswa secara bersama-sama berpengaruh terhadap prestasi belajar matematika mahasiswa PGSD dan PGMI. Selanjutnya yakni uji parsial dengan uji-t di dapatkan motivasi dan selfefficacy masing-masing berpengaruh terhadap prestasi belajar matematika mahasiswa PGSD dan mahasiswa PGMI sedangkan latar belakang pendidikan mahasiswa tidak berpengaruh terhadap prestasi belajar matematika mahasiswa PGSD dan mahasiswa PGMI.

Berdasarkan uji kesamaan menggunakan two-sample $t$ test (Dummy Variables in Regression: Testing for Parallelism and Comparing Two Intercepts) terdapat perbedaan pengaruh motivasi terhadap prestasi belajar matematika mahasiswa PGSD dan PGMI dilihat dari berbedanya slope dan intercept dari variabel motivasi sedangkan variabel self-efficacy tidak terbedaan slope tapi terdapat perbedaan pada intercept.

\section{Saran}

Bagi dosen yang berupaya untuk meningkatkan prestasi belajar matematika mahasiswa maka salah satu alternatif dengan meningkatkan motivasi dan self-efficacy mahasiswa.

Hasil penelitian yang didapatkan ini baru sampai pada tahap mengetahui pengaruh motivasi, self-efficacy dan latar belakang pendidikan mahasiswa terhadap prestasi belajar matematika mahasiswa PGSD dan PGMI. Dengan demikian hasil penelitian ini dapat dijadikan refrensi untuk melakukan penelitian selanjutnya. Disarankan bagi pengelola perguruan tinggi dan dosen untuk mencari solusi meningkatkan motivasi dan self-efficacy mahasiswa dalam pembelajaran matematika melalui penelitian lanjutan.

Kepada peneliti selanjutnya, diharapkan menyertakan variabel lain yang memungkinkan dapat mempengaruhi prestasi belajar matematika mahasiswa.

\section{DAFTAR PUSTAKA}

Arends, R.L., \& Kilcher, A. (2010). Teaching for student learning becoming an accomplished teacher. New York, NY: Routledge Published.

Azwar, Saifuddin (2012). Tes prestasi, fungsi dan pengembangan pengukuran prestasi belajar. Yogyakarta: Pustaka Pelajar Offset

Bandura, A (1997). Self-efficacy in changing societies. New York, NY: W.H. Freeman and Company

Berk, L.E. (2008). Infants, children, and adolesents sixt edition. Boston, MA: Pearson Education, Inc.

Brown, T., \& McNamara, O. (2005). New teacher identity and regulative Government the discursive formation of primary mathematics teacher education. New York. NY: Springer Science Business Media, Inc.

Friedman, H.S dan Schustack, M.W. (2008). Keperibadian teori klasik dan riset modern. (Terjemahan Firansiska Dian Ikarini, Maria Hany, \& Andreas Provita Prima). Upper Saddle River. NJ: Pearson Education, Inc. (Buku asli diterbitkan tahun 2006)

Kahn, P \& Kyle, J. (ed.) (2005). Effective learning \& teaching in mathematics \& its application. London: Stylus Publishing Inc

Kleinbaum, et.al (2008). Applied regression analysis and other multivariable method. Belmont, CA: Thomson Higher Education

NCTM. (2000). Principles and standars for school mathematics. Reston: The National Council of Teachers of Mathematics, Inc.

Santrock, J.W. (2008) Life-span development elevent edition. New York, NY: McGraw-Hill Companies,Inc

Santrock, J.W. (2011). Psikologi pendidikan edisi ke 2 (terjemahan Tri Wibowo). New York, NY: McGraw-Hill 
Companies. (Buku asli diterbitkan tahun 2004)

Santrock, J.W. (2011b). Educational psychology fifth edition. New York, NY: McGrawHill Companies

Schunk, D. H. (2012). Lerning theories (sixth edition). Boston, MA: Pearson Education, Inc.

Schwan, G.R. (Desember 2002). Achievement of learning standards as outcomes of services. Diambil pada tanggal 7 April 2013 dari http://sspw.dpi.wi.gov/files/ sspw/pdf/sswartic.pdf

Skemp, R.R. (1971). The psychology of learning mathematics.

Harmondsworth Middlesex: Penguin Books.

Suharningsih (2010). Optimalisasi kinerja guru dalam proses pembelajaran di sekolah dasar. Jurnal Paedagogia jilid 13, Nomor 2 Agustus 2010 halaman 103114 .

Suherman, Erman et.al (2001). Strategi pembelajaran matematika kontemporer. Bandung: JICA UPI

Stevens, J.P. (2009). Applied multivariate statistics for the social science fifth edition. New York, NY: Routledge Taylor \& Francis Group
Syah, Muhibbin. (2010). Psikologi pendidikan suatu pendekatan baru. Bandung: Remaja Rosdakarya.

Undang- Undang Nomor 20 tahun 2003 tentang Sistem Pendidikan Nasional

Van de Walle, J.A (2007). Elementary and middle school mathematics teaching development. Boston, MA: Pearson Education, Inc

Wade, C \& Tavris, C. (2007). Psokologi edisi kesembilan. (terjemahan oleh Padang mursalin \& Dinastuti). Upper Saddle River, NJ: Pearson Education, Inc. (Buku asli diterbitkan tahun 2006)

Wade, C \& Tavris, C. (2011). Psycology. Upper Saddle River, NJ: Pearson Education, Inc.

Waege, K. (January 2009). Motivation for learning mathematics in terms of needs and goals. Proceedings of CERME 6, January 28th-February 1st 2009, Lyon France (C) INRP 2010 diakses pada 7 April 2013 www.inrp.fr/editions/cerme6

Woolfolk, A, (2007). Educational psychology tenth edition. Boston, MA: Pearson Education, Inc

Zimmerman, B J., Sebastian, B, \& Robert K. (1996) Developing self-regulated learners beyond achievement to self efficacy. Washington, DC: American Psychological Association 